Vol. 04, No. 01 : Hal. 22 - 28

Februari 2019

\title{
PENGARUH BAHAN AJAR MIKROBIOLOGI BERBASIS INKUIRI TERHADAP KEMAMPUAN BERPIKIR KRITIS MAHASISWA IKIP BUDI UTOMO MALANG
}

\author{
Purwaning Budi Lestari ${ }^{1}$, Triasih Wahyu Hartati ${ }^{2}$ \\ ${ }^{1}$ Pendidikan Biologi, IKIP Budi Utomo, Malang \\ ${ }^{2}$ Pendidikan Jasmani Kesehatan dan Rekreasi, IKIP Budi Utomo, Malang \\ e-mail: purwaning.budilestari@gmail.com
}

\begin{abstract}
ABSTRAK
Kurangnya ketersediaan bahan ajar berbasis inkuiri menyebabkan pemikiran siswa menjadi kurang sistematis. Tujuan dari penelitian ini adalah untuk mengetahui pengaruh bahan ajar mikrobiologi berbasis inkuiri terhadap keterampilan berpikir kritis siswa di IKIP Budi Utomo. Jenis penelitian ini adalah eksperimen semu dengan uji validitas menggunakan metode korelasi bivariat menurut Pearson, sedangkan uji reliabilitas menggunakan metode Cronbach Alpha. Nilai pretest diuji menggunakan uji-t untuk sampel gratis, sedangkan perbedaan antara pretest dan posttest di kelas uji coba dianalisis menggunakan General Linear Model (GLM) - Measured Measures. Hasil penelitian menunjukkan bahwa ada pengaruh yang signifikan antara pengembangan bahan ajar berbasis inkuiri pada keterampilan berpikir siswa. Ini terbukti signifikan pada 0,000. Selain itu, ada perbedaan bermakna dalam keterampilan berpikir kritis, ada juga perbedaan rata-rata 19.000 untuk kelas kontrol dan 23,4285 di kelas perawatan. Berdasarkan hasil penelitian, dapat disimpulkan bahwa ada pengaruh bahan ajar mikrobiologi berbasis inkuiri terhadap kemampuan berfikir kritis siswa IKIP Budi Utomo.

Kata kunci: Bahan ajar mikrobiologi, berpikir kritis, inkuiri.
\end{abstract}

\section{ABSTRACT}

The lack of availability of inquiry-based teaching materials causes student thinking to be less systematic. The purpose of this study was to determine the effect of inquiry-based microbiology teaching materials on students' critical thinking skills at IKIP Budi Utomo. This type of research is quasi-experiment with testing validity using the bivariate correlation method according to Pearson, while reliability testing uses the Cronbach Alpha method. The pretest values were tested using the t-test for free samples, while the difference between pretest and posttest in the trial class was analyzed using the General Linear Model (GLM) Repeated Measures. The results of the study showed that there was a significant influence between the development of inquiry-based instructional materials on students' thinking skills. This is shown to be significant at 0,000 . In addition, there are meaningful differences in critical thinking skills, there are also mean differences of 19,000 for the control class and 23.4285 in the treatment class. Based on the results of the study, it can be concluded that there is an influence of inquiry-based microbiology teaching materials on the critical thinking ability of Budi Utomo IKIP students.

Keywords: Microbiology teaching materials, critical thinking, inquiry.

Submitted: 18 Februari Accepted: 12 Juni $2019 \quad$ Published: 05 Juli 2019

\section{PENDAHULUAN}

Penggunaan buku ajar di perguruan tinggi sangat diperlukan, khusunya buku ajar yang dapat mengakomodasi peningkatan keterampilan berpikir yang lebih terintegrasi. Menurut (Shebaa, 2013), bahwa kegiatan pembelajaran Biologi hendaknya dapat mengembangkan keterampilan proses karena

DOI: 10.33503/ebio.v4i01.307

Copyright (C2019, Edubiotik: Jurnal Pendidikan, Biologi dan Terapan 
Vol. 04, No. 01 : Hal. 22 - 28

Februari 2019

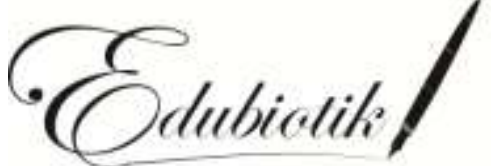

hal tersebut dapat mengembangkan keterampilan yang terintegrasi. Menurut Kemendiknas (2010) komponen pembelajaran yang paling berpengaruh terhadap proses pembelajaran adalah bahan ajar.

Penggunaan bahan ajar mempunyai peranan yang sangat penting dalam meningkatkan proses pemahaman khususnya pembelajaran sains karena keberhasilan pembelajaran ditentukan oleh tinggi rendahnya penguasaan materi oleh peserta didik (Sanjaya. 2010). Penggunaan bahan ajar berupa buku ajar dapat membantu peningkatan keberhasilan sebuah pembelajaran. Buku ajar merupakan seperangkat materi yang berisi substansi pelajaran yang disusun secara sistematis dan menampilkan keutuhan dari kompetensi yang akan dikuasai oleh siswa dalam kegiatan pembelajaran.

Menurut (Hartati. 2017), IKIP Budi utomo Malang merupakan salah satu Lembaga Pendidikan Tenaga Keguruan (LPTK) yang salah satu tujuannya adalah mencetak guru yang profesional. Untuk mewujudkan hal itu harus didukung oleh adanya sarana prasana yang mendukung terpenuhinya media pembelajaran. Diantara media pembelajaran tersebut adalah tersedianya buku ajar yang mempunyai konsep secara sistematis dan bertumpu pada peningkatan pemberdayaan berpikir kritis berupa buku ajar berbasis inkuiri. Menurut (Llewellyn, 2013), dikatakan bahwa pembelajaran berbasis inkuiri adalah pembelajaran yang menggunakan pendekatan yang sesuai dengan karakteristik pembelajaran sains yang didasarkan pada tahapan kerja ilmiah serta mampu mengembangkan sikap serta keterampilan sains siswa.

Kemampuan mahasiswa dalam menganalisis sebuah konsep akan mencerminkan seberapa besar kemampuan mahasiswa dalam berpikir yang merupakan dasar dari sebuah proses pembelajaran (Heong et al. 2011). Indikator seseorang mempunyai kemampuan berpikir kritis ketika mereka mampu berpikir secara intelektual. Hal ini seperti pendapat oleh (Paul \& Helder. 2005 dalam Wahyuni. S, dkk. 2015)bahwa berpikir kritis dilakukan seseorang untuk meningkatkan kualitas hasil pemikiran secara sistematis sehingga menghasilkan pemikiran yang intelektual. Seperti yang disampaikan oleh (Yeretia Suci, dkk 2017) bahwa berpikir kritis memungkinkan peserta didik untuk menganalisis pikirannya dalam menentukan pilihan dan menarik kesimpulan dengan cerdas.

Mikrobiologi merupakan salah satu bidang ilmu yang di dalamnya terdapat materi tentang mikroorganisme terutama bakteri, fungi, virus, dan implementasi mikrobiologi terhadap kehidupan sehari-hari. Keseluruhan materi mikrobiologi menekankan kegiatan pembelajaran sistematis dan memerlukan peningkatan keterampilan yang terintegrasi. Akan tetapi selama ini buku mikrobiologiyang digunakan kurang mampu mengakomodasi hal tersebut. Hasil observasi dilapangan menemukan fakta bahwa penggunaan buku teks mikrobiologi yang sudah ada seringkali membuat mahasiswa justru kesulitan dalam menggunakannya.

Penggunaan bentuk tes berupapilihan ganda perlu diubah agar mahasiswa memiliki tingkat berpikir yang lebih tinggi (Ismiati.L. 
Vol. 04, No. 01 : Hal. 22 - 28

Februari 2019

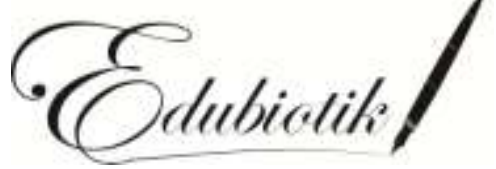

2011). Kemampuan berpikir kritis merupakan aktivitas berpikir tingkat tinggi. Berpikir merupakan suatu kegiatan untuk mengetahui pengetahuan yang benar (Suriasumantri, 2005 dalam Zubaidah, 2007) yang berarti bahwa seseorang harus dapat membedakan pengetahuan yang benar untuk dikembangkan sehingga dapat mengambil langkah yang benar.

Oleh karena itu untuk mengetahui pengaruh pengunaan buku ajar berbasis inkuiri terhadap kemampuan berpikir kritis mahasiswa maka peneliti akan melakukan penelitian tentang pengaruh buku ajar mikrobiologi berbasis inkuiri terhadap kemampuan berpikir kritis mahasiswa di IKIP Budi Utomo Malang. Adapun tujuan dalam penelitian ini adalahuntuk mengetahui pengaruh bahan ajar berbasis inkuiri terhadap kemampuan berpikir kritis mahasiswa pada mata kuliah mikrobiologi di IKIP Budi Utomo Malang.

\section{METODE PENELITIAN}

Jenis penelitian ini adalah quasiexperiment dengan tujuan membandingkan pembelajaran menggunakan bahan ajar berbasis inkuiri. Sampel dalam penelitian ini adalah mahasiswa program studi biologi angkatan 2016. Waktu pelaksanaan semester genap 2017/2018. Teknik analisis data mencakup uji homogenitas penelitian, Nilai pretes dan postes kelompok subjek diuji perbedaannya. Nilai pretes diuji dengan menggunakan uji-t untuk sampel bebas, sedangkan perbedaan antara pretes dengan postes pada kelas uji coba dianalisis dengan menggunakan General Linear Model (GLM) - repeated Measures, Perbedaan nilai postes, nilai kemampuan berpikir kritis, dianalisis dengan menggunakan General Linear Model (GLM)-Multivariate.

\section{HASIL DAN PEMBAHASAN}

Uji homogenitas dilakukan terhadap data postes terkoreksi. Hasil uji homogenitas ditampilkan pada Tabel 1. Berdasarkan perhitungan diperoleh signifikasi (p.level) lebih besar dari 0,05 (p.0,05), hal ini menunjukkan bahwa $\mathrm{HO}$ diterima, jadi varian antar kelompok data tidak berbeda atau homogen.

Tabel 1. Hasil Uji Homogenitas

\begin{tabular}{cccc}
\hline Levene Statistic & df1 & df2 & Sig. \\
1.089 & 8 & 25 & .403 \\
\hline
\end{tabular}

Hasil penelitian kemampuan berpikir kritis menunjukkan adanya perbedaan rerata kemampuan berpikir kritis mahasiswa antara kelas kontrol sebesar19.000dengan kelas perlakukan sebesar 23.429. Pada uji eksperimen diketahui terdapat perbedaan yang signifikan antara kelas perlakuan dengan kelas kontrol dengan taraf signifikan menunjukkan 0.000. Ringkasan uji statistik terdapat pada Tabel 2 dan ringkasan uji statistic untuk mengetahui taraf signifikan terdapat pada tabel 3 Berikut.

Hasil uji statistik pada Tabel 3 menunjukkan bahwa terdapat pengaruh yang signifikan dengan penggunaan bahan ajar berbasis inkuiri terhadap kemampuan berpikir kritis mahasiswa. Hal ini ditunjukkan dengan taraf signifikan 0.00.

Berdasarkan hasil analisis statistik terdapat pengaruh yang signifikan penggunaan buku ajar terhadap kemampuan 
Vol. 04, No. 01 : Hal. $22-28$

Februari 2019

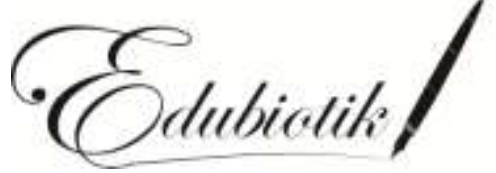

P-ISSN: 2528-679X

E-ISSN: 2597-9833

berpikir kritispada mahasiswa IKIP Budi dapat memecahkan sebuah permasalahan Utomo khususnya matakuliah mikrobiologi. Hal ini disebabkan melalui pembelajaran dengan menemukan jawaban melalui kegiatan pembelajaran yang sistematis.

inkuiri yang diterapkan terhadap mahasiswa

Tabel 2. Ringkasan Uji Statistik Deskriptif Kemampuan Berpikir Kritis

One-Sample Statistics

\begin{tabular}{llrrrr}
\hline & Statistic & \multicolumn{3}{c}{ Bootstrap $^{\text {a }}$} \\
\cline { 5 - 7 } & & & Bias & Std. Error & $\begin{array}{c}\text { 95\% Confidence Interval } \\
\text { Lower }\end{array}$ \\
Upper
\end{tabular}

Table 3.Uji Statistik untuk Mengetahui Signifikasi antara Kelas Kontrol dan Perlakuan.

\begin{tabular}{|c|c|c|c|c|c|c|}
\hline & \multicolumn{6}{|c|}{$\begin{array}{r}\text { One-Sample Test } \\
\text { Test Value }=0\end{array}$} \\
\hline & \multirow[t]{2}{*}{$\mathbf{T}$} & \multirow[t]{2}{*}{ Df } & \multirow[t]{2}{*}{ Sig. (2-tailed) } & \multirow[t]{2}{*}{$\begin{array}{c}\text { Mean } \\
\text { Difference }\end{array}$} & \multicolumn{2}{|c|}{$\begin{array}{l}\text { 95\% Confidence Interval of the } \\
\text { Difference }\end{array}$} \\
\hline & & & & & Lower & Upper \\
\hline BK_kontrol & 39.888 & 34 & .000 & 19.0000 & 18.032 & 19.968 \\
\hline BK_perlakuan & 55.174 & 34 & .000 & 23.4286 & 22.566 & 24.292 \\
\hline
\end{tabular}

Selain itu melalui pembelajaran inkuiri mahasiswa dapat memperoleh pengetahuan dengan menemukan sendiri jawaban dari permasalahan yang mereka hadapi.Seperti yang disampaikan oleh Wahyudi dan Supardi (2013), menyatakan bahwa model pembelajaran inkuiri terbimbing merupakan model pembelajaran yang membantu siswa untuk belajar dan membantu mereka memperoleh pengetahuan dengan cara menemukan sendiri konsep yang sedang mereka pelajari. Sejalan dengan penelitian oleh Nur'Azizah et al (2016)dalam penelitiannya dijelaskan bahwa kemampuan berpikir kritis peserta didik dapat meningkat melalui model inkuiri terbimbing. Pembelajaran inkuiri dapat meningkatkan kemampuan berpikir kritis karena melibatkan keaktifan mental dan proses kognitif. Sebagaimana hakekat berpikir kritis merupakanproses mental yang bertujuan untuk menghasilkan sebuahkeputusanyanglogis tentang sesuatu yang harus diyakini dan dilakukan. Seperti yang disampaikan oleh Michael Scriven dan Richard Paul (dalam Nurmaliah, 2009) berpikir kritis dapat diartikan sebagai proses dan kemampuan yang keduanya digunakan untuk memahami konsep, menerapkan, mensintesa, dan mengevaluasi informasi yang didapat serta informasi yang dihasilkan. Beberapa aspek yang berhubungan dengan berpikir kritis antara lain menurut Wahyuni. S. dkk. 2015 meliputi:kejelasan (clarity), tingkat akurasi (accuracy), presisi (precision), relevansi (relevance), logika berpikir yang digunakan 
Vol. 04, No. 01 : Hal. 22 - 28

Februari 2019

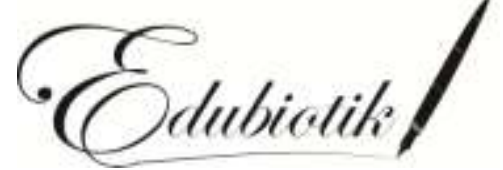

P-ISSN: 2528-679X

E-ISSN: 2597-9833

(logic), keluasan sudut pandang (breadth, kedalaman berpikir (depth), kejujuran (honesty) tetap, kelengkapan informasi information), dan implikasi dari solusi yang dikemukakan (implication).

Pemberdayaan kemampuan berpikir kritis selama pembelajaran mikrobiologi sangat penting dan strategis untuk meningkatkan kemampuan mahasiswa. Kemampuan berpikir kritis memberikan arahan yang tepat dalam berpikir, bekerja, dan membantu menemukan keterkaitan permasalahan dengan informasi yang lainnya dengan lebih akurat. Oleh sebab itu kemampuan berpikir kritis sangat dibutuhkan dalam pemecahan masalah atau pencarian. Sehubungan dengan hal tersebut, Corebima (2006) menyatakan bahwa pemberdayaan berpikir selama pembelajaran biologi sangat penting. Hasil penelitian sebelumnya menunjukkan adanya hubungan antara penalaran formal, prestasi belajar dengan keterampilan berpikir kritis. misal: ada hubungan yang signifikan antara kemampuan penalaran formal dan skor hasil ujian pada perkuliahan genetika (Walker, 1979; Susilo dkk, 2004) dalam (Ismiati. L, 2011) dimana mahasiswa yang memiliki penalaran formal perkuliahan umum memiliki audio-tutorial lebih baik dan menguasai perkuliahan, ketrampilan laboratorium, serta lebih mampu berpikir kritis daripada mereka yang memiliki penalaran konkrit. Berpikir kritis menurut Arend (2001), dalam Ismiati. L (2011) berpikir adalah proses yang melibatkan operasi mental seperti induksi, deduksi, klasifikasi, dan penalaran. Secara umum berpikir merupakan proses kognitif dan aktivitas mental sehingga pengetahuan dapat diperoleh (Pressein, 2001, dalam
Ismiati. L. 2011). Menurut Ruch (1996), dalam kurniawan 2002) berpikir merupakan manipulasi atau organisasi unsur-unsur lingkungan dengan menggunakan lambanglambang sehingga tidak perlu langsung melakukan kegiatan yang tampak.Berpikir merujuk pada berbagai aktifitas yang melibatkan penggunaan lambang dan konsep sebagai pengganti obyek dan peristiwa. Berpikir kritis merupakan suatu aktifitas kognitif yang berkaitan dengan penggunaan nalar. Penalaran merupakan salah satu bentuk berpikir untuk mencapai kesimpulan.

Implementasi pengembangan bahan ajar mikrobiologi berbasis inkuiri pada kegiatan pembelajaran setelah dianalisis terdapat pengaruh yang signifikan antara bahan ajar terhadap kemampuan berpikir kritis. Seperti penelitian olah Suci Yeritia, dkk (2017) menyebutkan ada pengaruh model pembelajaran inkuiri terbimbing terhadap penguasaan konsep dan kemampuan berpikir kritis peserta didik kelas X SMAN 1 Kuripan tahun ajaran 2017/2018. Penggunaan bahan ajar berbasis inkuiri pada mata kuliah mikrobiologi menyebabkan keaktifan siswa meningkat pada saat proses pembelajaran sedang berlangsung. Keaktifan siswa terjadi karena pembelajaran melalui pendekatan inkuiri mempunyai tahapan diantaranya siswa mampu merumuskan sebuah permasalahan, mengajukan hipotesis, pengumpulan data melalui kegiatan ilmiah, dan mampu untuk menyelesaiakan sebuah permasalahan.

\begin{tabular}{lccr}
\multicolumn{2}{c}{ Adanya } & kelebihan-kelebihan pada \\
pembelajaran & inkuiri yang & dapat \\
menekankan secara seimbang pada & afektif, \\
pengembangan & aspek kognitif, afektan
\end{tabular}


Vol. 04, No. 01 : Hal. 22 - 28

Februari 2019

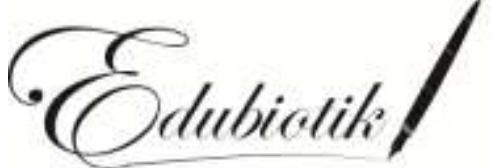

P-ISSN: 2528-679X

E-ISSN: 2597-9833

pembelajaran inkuiri yang terdapat dalam buku ajar dapat menekankan aktivitas siswa secara maksimal untuk mencari dan menjawab sebuah permasalahan yang terdapat dalam materi pembelajaran, sehingga siswa ditempatkan sebagai subjek belajar dengan demikian siswa dapat mengembangkan kemampuan berpikir secara sistematis, logis, dan kritis. Seperti penelitian yang dilakukan oleh Nugroho. S, dkk (2012) dari hasil uji statistik tentang prestasi belajar kognitif menunjukkan $P$ value bernilai 0,000 , sehingga dapat disimpulkan terdapat pengaruh yang signifikan pembelajaran inkuiri terbimbing menggunakan laboratorium riil dan laboratorium virtuil terhadap prestasi belajar kognitif.

Sistematika penyusunan buku ajar berbasis inkuiri memuat beberapa komponen seperti gambar-gambar yang disajikan secara menarik dan warna-warna yang kontras, hal ini diharapkan dapat membantu mahasiswa dalam membangun pemahaman materi pembelajaran. Beberapa manfaat adanya buku ajar diantaranya dapat digunakan sebagai sumber ilmu pengetahuan yang dapat membantu meningkatkan mutu proses dan hasil pembelajaran. Menurut Syahfitri. H. (2016) beberapa tujuan pembuatan bahan ajar diantaranya sebagai sumber informasi dalam kegiatan pembelajaran; sebagai pendukung utma dalam proses pembelajaran; dan sebagai media pembelajaran yang membantu dalam proses pembelajaran.

Penggunaan buku ajar berbasis inkuiri sangat membantu mahasiswa dalam memecahkan sebuah permasalahan melalui kegiatan yang bersifat ilmiah. Seperti penelitian yang dilakukan oleh Prihatin dkk.
(2017) hasil penelitiannya menyebutkan Modul berbasis inkuiri terbimbing efektif meningkatkan kemampuan berpikir kritis, karena berdasarkan hasil uji anakova menunjukkan adanya perbedaan hasil postes antara kelas eksperimen dan kelas kontrol pada materi ajar jamur sebesar 39,2\%. Hal ini karena mahasiswa dapat berpikir secara ilmiah.

Menurut Dewi (2013), model pembelajaran inkuiri terbimbing menekankan pada proses penemuan sebuah konsep sehingga muncul sikap ilmiah pada diri siswa dan dapat dirancang penggunaannya oleh guru menurut tingkat perkembangan intelektual siswa. Senada dengan Wahyudi dan Supardi (2013), menyatakan bahwa model pembelajaran inkuiri terbimbing merupakan model pembelajaran yang membantu siswa untuk belajar, membantu mereka memperoleh pengetahuan dengan cara menemukan sendiri apa yang sedang mereka pelajari. Di dalam model ini juga tercakup penemuan makna, organisasi, dan struktur dari ide atau gagasan, sehingga secara bertahap siswa belajar bagaimana mengorganisasikan dan melakukan penelitian guna mencapai tujuan pembelajaran.

\section{SIMPULAN DAN SARAN}

Kesimpulan dalam penelitian ini adalah terdapat pengaruh yang signifikan antara bahan ajar mikrobiologi berbasis inkuiri terhadap kemampuan berpikir kritis mahasiswa IKIP Budi Utomo. Saran untuk mengetahui efektifitas pengembangan bahan ajar mikrobiologi berbasis inkuiri secara optimal maka dapat diberi wadah dalam penelitian selanjutnya agar dapat 
Vol. 04, No. 01 : Hal. 22 - 28

Februari 2019

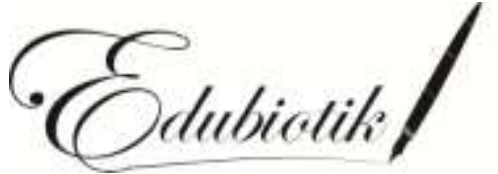

P-ISSN: 2528-679X

E-ISSN: 2597-9833

mengimplementasikan buku ajar tersebut di beberapa perguruan tinggi.

\section{RUJUKAN}

Hartati Tria Asih W dan Dini Safitri. (2017). 'Pemberdayaan Kemampuan Berpikir Kritis Melalui Penerapan Model Siklus Belajar5E berbasis Lesson Study pada Mahasiswa IKIP Budi Utomo', Jurnal EFEKTOR ISSN. 2355-956X; 23557621 http://ojs.unp kediri.ac.id

Ismiati, L. (2011). 'Pengaruh Strategi Think Pair Share, Reciprocal Teaching dan Integrasinya terhadap Hasil Belajar Kognitif Biologi dan Kemampuan Berpikir Kritis Peserta didik Berkemampuan Akademik Berbeda di R-SMA-BI Negeri Batu. Tesis tidak diterbitkan'. Malang: PPs UM

Kemdiknas. (2010). Pendidikan Karakter Di Sekolah Menengah Pertama. Jakarta: Ditjen mandikdasmen.

Llewellyn, Douglas. (2013). Teaching High School Science Through Inquiry and Argumentation: Second Edition. USA: Corwin Press.

Moog, R.S., Creegan, F.J., Hanson, D.M, Spencer, J.N, Straumanis, A. \& Bunce, D.M. (2009). 'POGIL: Process-Oriented Guided-Inquiry Learning. Dalam N.J. Pienta., M.M. Cooper. \& T.J. Greenbowe (Eds.)', Chemists' Guide to Effective Teaching Volume II, (90-101). USA: Pearson Prentice Hall.

Nur'Azizah, H., Jayadinata, A. P., Gusrayani, D. (2016). 'Pengaruh Model Pembelajaran Inkuiri Terbimbing

terhadap Kemampuan Berpikir Kritis Siswa Pada Materi Energi Bunyi', Jurnal Pena Ilmiah. 1(1),51-60.

Rasulun Iman, Ibnu Khaldun, Nasrullah. (2017). Meningkatkan Kemampuan Berpikir KritisSiswa Dengan Model Inkuiri Terbimbing Pada Materi Pesawat Sederhana. Jurnal Pendidikan Sains Indonesia, Vol. 05, No.01, hlm 52-58, 2017 http://jurnal.unsyiah.ac.id/jpsi

Sadeh, I. \& Zion, M. (2009). 'The Development of Dynamic Inquiry Performances within an Open Inquiry Setting: A Comparison to Guided Inquiry Setting', Journal of Research in Science Teaching, 46 (10): 1137-1160.

Suci Yeritia, Wahyudi, Satutik Rahayu. (2017). Pengaruh Model Pembelajaran Inkuiri Terbimbing Terhadap Penguasaan Konsep Dan Kemampuan Berpikir Kritis Fisika Peserta Didik Kelas X SMAN 1 Kuripan TAHUN AJARAN 2017/2018', Jurnal Pendidikan Fisika Dan tehnologi Vol.3 No. 22017.

Sheeba, M. N. (2013). 'An Anatomy of Science Process Skills in The Light of the Challenges to Realize Science Instruction Leading to Global Excellence in Education', Educationia Confab, 2 (4):108-123.

Sri Wahyuni, Rr. Eko Susetyarini, Roimil Latifa. (2015). 'Peningkatan Kemampuan Berpikir Kritis Mahasiswa Pendidikan Biologi UMM Melalui Lesson Study', JINoP (Jurnal Inovasi Pembelajaran) Volume 1, Nomor 2, November 2015. 